\title{
Enantioselective Coupling of Nitroesters and Alkynes
}

\author{
Ryan T. Davison, Patrick D. Parker, Xintong Hou, Crystal P. Chung, Sara A. Augustine, and Vy M. Dong* \\ Department of Chemistry, University of California, Irvine, Irvine, 92697, United States
}

\begin{abstract}
By using $\mathrm{Rh}-\mathrm{H}$ catalysis, we couple $\alpha$-nitroesters and alkynes to prepare $\alpha$-amino acid surrogates. This atom-economical strategy generates two contiguous stereocenters, with high enantioand diastereocontrol. In this transformation, the alkyne undergoes isomerization to generate a $\mathrm{Rh}(\mathrm{III})-\pi$-allyl electrophile, which is trapped by an $\alpha$-nitroester nucleophile. A subsequent reduction with In powder transforms the allylic $\alpha$-nitroesters to the corresponding $\alpha, \alpha$ disubstituted $\alpha$-amino esters.
\end{abstract}

By designing and synthesizing $\alpha$-amino acids ( $\alpha$-AAs), chemists have expanded the genetic code, shed light on protein function, and invented medicines. ${ }^{[1-3]}$ The $\alpha, \alpha$-disubstituted $\alpha$-AAs and related analogs attract interest due to their metabolic stability, unique conformations, and potent bioactivity (Figure 1) ${ }^{[4]}$ Enantioenriched $\alpha, \alpha$-disubstituted $\alpha$-AAs are targeted by various strategies, including phase-transfer catalysis, organocatalysis, and transition-metal catalysis. ${ }^{\left[{ }^{5}\right.}$ Despite an interest in these motifs, methods for the enantio- and diastereoselective preparation of $\alpha, \alpha$-disubstituted $\alpha$-AAs bearing contiguous stereocenters remain sought after; ${ }^{[6]}$ emerging reports feature pre-functionalized allylic partners (e.g., allylic carbonates). The direct addition of an amino acid surrogate to a $\pi$-system represents an attractive approach to $\alpha, \alpha$-disubstituted $\alpha$-AAs. Towards this end, $\mathrm{Zi}$ and coworkers exploited synergistic $\mathrm{Pd} / \mathrm{Cu}$ catalysis for the stereodivergent coupling of aldimine esters and 1,3-dienes. ${ }^{[7]}$ In a complementary approach, we propose using a Rh-hydride $(\mathrm{Rh}-\mathrm{H})$ catalyst to couple $\alpha$-nitrocarbonyls and alkynes to generate the corresponding $\alpha$-AA surrogates. This atom-economical ${ }^{[8]}$ coupling exploits two simple functional groups and provides rapid access to analogs for the building blocks of life. ${ }^{[9]}$

Inspiration: biologically active $\alpha, \alpha$-disubstituted $\alpha$-AAs and analogs<smiles>NC(N)(Cc1ccccc1)C(=O)O</smiles>

$\alpha$-methyl-L-Phe ( $\beta$-turn former)<smiles>C[C@@](N)(Cc1ccc(O)c(O)c1)C(=O)O</smiles>

$$
\text { methyldopa (aldomet) }
$$
(antihypertensive)

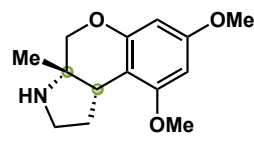

3-amino-chromane (lead for $\sigma_{1}$ receptor)
- Hydrofunctionalization: synthesis of $\alpha$-AAs with contiguous stereocenters -
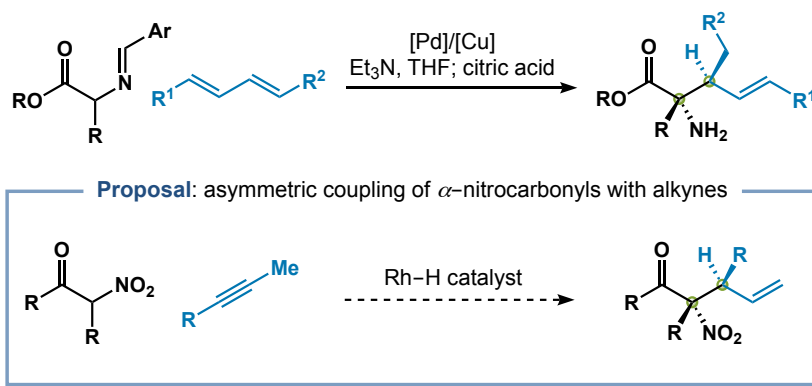

Figure 1. Enantioselective preparation of $\alpha$-AAs and analogs.
On the basis of literature precedent, ${ }^{[10]}$ we envisioned a tandem catalytic cycle for the asymmetric coupling of $\alpha$-nitrocarbonyls 1 and alkynes 2 to yield $\alpha$-AA surrogates 3 (Figure 2). Wolf and Werner discovered that $\mathrm{Rh}-\mathrm{H}$ complexes isomerize alkynes (2) via an allene intermediate (4) to form Rh- $\pi$-allyl species IV . ${ }^{[11]}$ By using this isomerization, the Breit laboratory achieved asymmetric and catalytic couplings of alkynes with a wide-range of heteroatom nucleophiles to afford branched allylic products. ${ }^{[12]}$ In comparison, the analogous coupling of alkynes with carbon nucleophiles remains more limited, with only three asymmetric variants. ${ }^{[13]}$ Of these three reports, only two afford products that contain vicinal stereocenters. We showed that aldehydes couple to alkynes with high enantio- and diastereoselectivity when using a chiral Rh-H catalyst in synergy with a chiral amine cocatalyst. ${ }^{[13 a]}$ Xing and coworkers expanded this approach for the coupling of ketones with alkynes, but the use of an achiral amine co-catalyst furnishes the branched products with little to no diastereocontrol. ${ }^{[13 c]}$

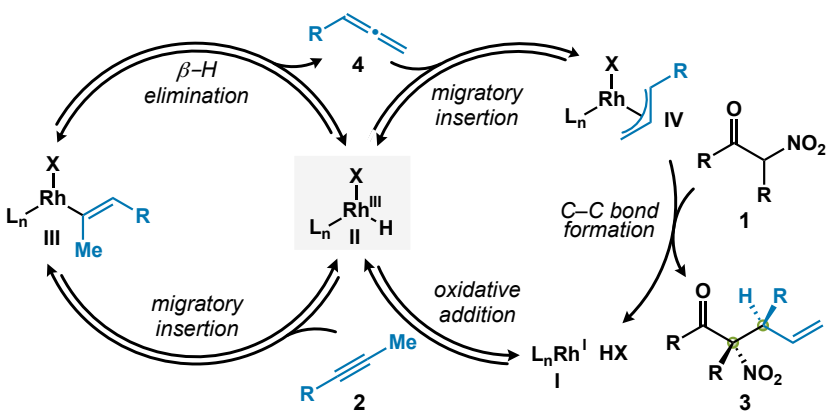

Figure 2. Proposed mechanism for Rh-catalyzed allylation.

In related studies, we and others have shown that 1,3dicarbonyls can couple to alkynes to generate branched allylic carbonyl motifs. ${ }^{[14]}$ Promising reactivity and regioselectivity has been achieved. However, obtaining high levels of enantio- and diastereoselectivity has been challenging. It occurred to us that $\alpha$ nitrocarbonyls display comparable chelation aptitude ${ }^{[15]}$ and acidity $\left(\mathrm{p} K_{\mathrm{a}}=\mathrm{ca} .8\right)^{[16]}$ to 1,3 -dicarbonyls. Thus, we imagined $\alpha$ nitrocarbonyls would be suitable nucleophiles for trapping Rh- $\pi$ allyl species IV. With this design in mind, we set out to couple $\alpha$ nitrocarbonyls and alkynes with enantio- and diastereocontrol.

In initial studies, we discovered that various $\alpha$-nitrocarbonyls add to the commercially available alkyne $\mathbf{2 a}$ (Table 1 ). Using a combination of $\left[\mathrm{Rh}(\operatorname{cod}) \mathrm{Cl}_{2}\right.$, dppf, and diphenyl phosphate, we observe allylic $\alpha$-nitroketone, $\alpha$-nitroester, and $\alpha$-nitroamide products as single regioisomers $(>20: 1 \mathrm{rr}$ ) with moderate to high diastereoselectivity (5:1-12:1 dr). In accordance with previous reports, there is a preference for the branched regioisomer, which bears two contiguous stereocenters. ${ }^{[10 a-d, 12-14]}$ Our findings complement an enantioselective Pd-catalyzed $\alpha$-nitroester allylation reported by Ooi and coworkers. ${ }^{[17]}$ In Ooi's study, the use of allylic carbonates affords linear regioisomers with one stereocenter. 
Table 1. Investigating various $\alpha$-nitrocarbonyls. ${ }^{\text {[a] }}$
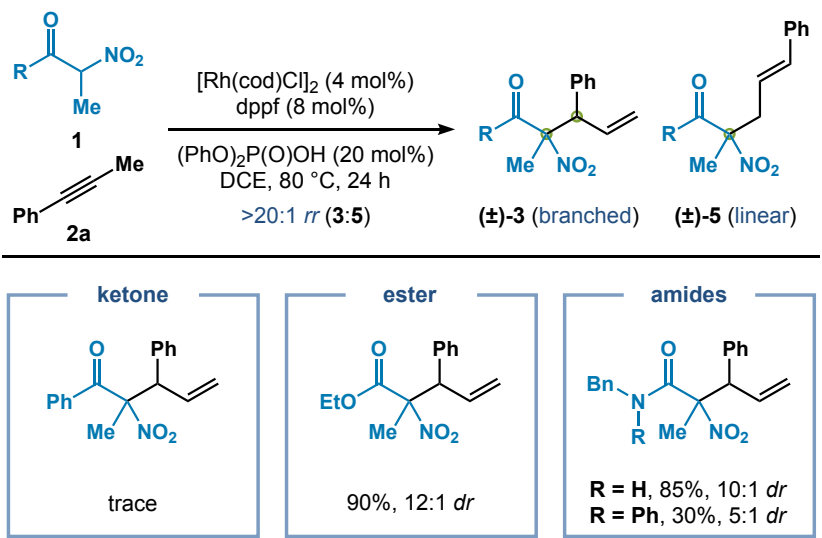

[a] See SI for reaction conditions. Yields determined by ${ }^{1} \mathrm{H}$ NMR referenced to an internal standard.

Next, we focused on an enantioselective variant for the coupling of $\alpha$-nitroesters with alkynes because the resulting motifs are readily converted to $\alpha$-AAs. ${ }^{[18]}$ To identify the appropriate chiral catalyst, we selected $\alpha$-nitroester $1 \mathrm{a}$ and 1-phenyl-1-propyne (2a) as the model substrates (Table 2). Using atropoisomeric bisphosphine ligands L1-L3 with a range of dihedral angles, ${ }^{[19]}$ we observe the allylic $\alpha$-AA surrogate 3aa with moderate yields (45-53\%) and enantioselectivities (85:15-90:10 er). Ultimately, we found that commercial MeO-BIPHEP ligand L6 bearing bis(3,4,5-trimethoxyphenyl)phosphino groups affords 3aa in $90 \%$ yield with $97: 3 \mathrm{er},>20: 1 \mathrm{dr}$, and $>20: 1 \mathrm{rr}$ on preparative scale (1 $\mathrm{mmol}) \cdot{ }^{[20,21]}$

Table 2. Survey of chiral ligands. ${ }^{[a]}$
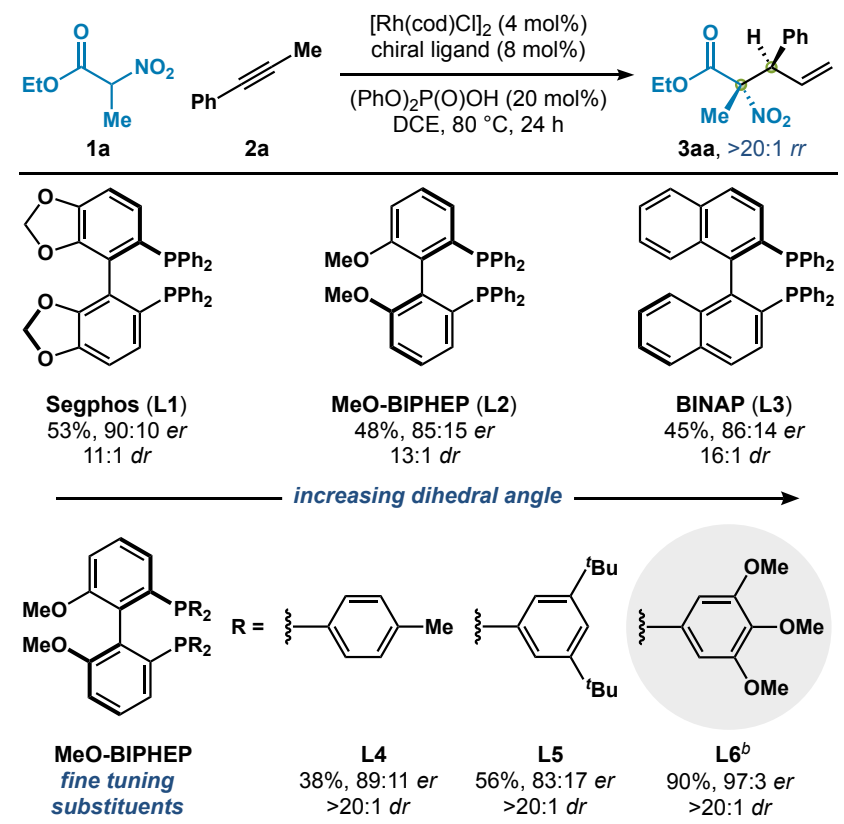

[a] See SI for reaction conditions. Yields determined by ${ }^{1} \mathrm{H}$ NMR referenced to an internal standard. [b] Isolated yield for a $1 \mathrm{mmol}$ reaction.
With this protocol, we explored the asymmetric coupling of various $\alpha$-nitroesters with 2a (Table 3 ). Analogs of ethylalanine (3ba), leucine (3da), methionine (3ea), phenylalanine (3fa), 4fluoro-phenylalanine (3ga), tyrosine (3ha), and tryptophan (3ia) are generated with moderate to high yields (34-84\%) with excellent levels of enantioselectivity $(\geq 95: 5 \mathrm{er})$. The absolute configuration of $\mathbf{3 f a}$ was confirmed by $\mathrm{X}$-ray crystallographic analysis. ${ }^{[20,21]}$ In the case of lower yielding substrates, we often recover $\alpha$-nitroester $1{ }^{[20]}$ The bulkier $\beta$-branched $\alpha$-nitroesters 1c and $\mathbf{1 j}$ do not couple to $2 \mathbf{a}$ to form analogs of valine (3ca) and phenylglycine (3ja), respectively. Alkyl-substituted esters $\mathbf{3 k a -}$ 3na provide higher reactivity than aryl ester 3oa. We see high levels of diastereocontrol (>20:1 dr) for forming 3ka and 3la, which suggests the $\mathrm{C}-\mathrm{C}$ bond is forged by catalyst control.

Table 3. $\alpha$-Nitrocarbonyl scope. ${ }^{\text {[a] }}$

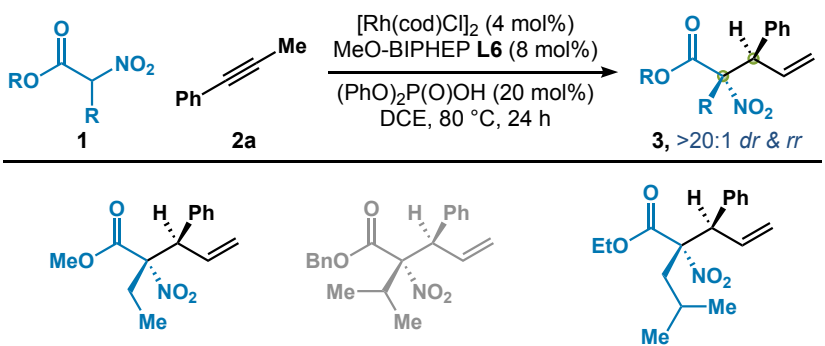

3ba, $84 \%, 95: 5$ er

3ca, not observed 3da, 35\%, 97:3 er<smiles>C=C[C@H](c1ccccc1)[C@H](CCSC)C(=O)OCc1ccccc1</smiles><smiles>C#CC=C[C@H](c1ccccc1)[C@@](Cc1ccccc1)(C(=O)OCC)[N+](=O)[O-]</smiles>

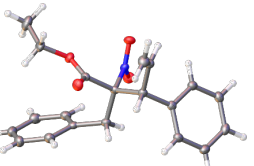

3ea, $34 \%, 97: 3 \mathrm{er}^{b, c}$

3fa, 57\%, 96:4 er

$$
\text { 3fa, [X-ray] }
$$<smiles>C=C[C@H](c1ccccc1)[C@@](Cc1ccccc1)(Cc1ccc(F)cc1)C(=O)OCC</smiles><smiles>C=C[C@H](c1ccccc1)[C@H](Cc1ccc(OC)cc1)[C@](Cc1ccccc1)(OCC)C(=O)OCC</smiles><smiles>C=C[C@H](c1ccccc1)[C@H](Cc1c[nH]c2ccccc12)C(=O)OCc1ccccc1</smiles>

3ga, $49 \%, 95: 5 e r^{c}$ 3ha, 38\%, 98:2 er ${ }^{c}$ 3ia, $65 \%, 98: 2 e r^{d}$

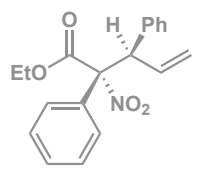

3ja, not observed<smiles>C/C=C\C(c1ccccc1)[C@H](C)[C@](C)(O)C(=O)O[C@H]1CC(C)CC[C@@H]1C(C)C</smiles><smiles>C/C=C\C(c1ccccc1)[C@H](/C=C\C)[C@](C)(O)[N+](=O)[O-]</smiles>
3ka, $86 \%$ 3la, $72 \%$<smiles>C=C[C@H](c1ccccc1)[C@](C)(C(=O)OC1CCCCC1)[N+](=O)[O-]</smiles><smiles>C=CC(c1ccccc1)[C@H](C(=O)OCc1ccccc1)[N+](=O)[O-]</smiles>

3na, 89\%, 95:5 er

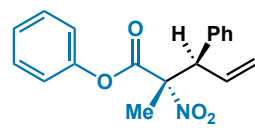

3oa, $24 \%, 84: 16$ er

[a] Isolated yields. See SI for reaction conditions. [b] 6:1 $d r$. [c] Yields based on recovered starting material (brsm): 3ea $(76 \%)$, 3ga $(96 \%)$, and 3ha $(65 \%)$. [d] $[\mathrm{Rh}(\mathrm{cod}) \mathrm{Cl}]_{2}(8 \mathrm{~mol} \%)$ and $\mathbf{L 6}(16 \mathrm{~mol} \%)$ instead of standard conditions.

Table 4 captures results from our study on the coupling of 1 a with various alkynes 2 . Aryl alkynes possessing a variety of electronics and substitution patterns participate in the asymmetric coupling (3ab-3al and 3ao). Alkynes bearing halides (2b, 2c, $\mathbf{2 h}$, $\mathbf{2 i}$ and $\mathbf{2 l}$ ), carbonyls (2d and 2f), and extended $\pi$-systems (2o) transform to the corresponding allylic $\alpha$-nitroesters 3 . Aryl alkynes 
with electron-donating substituents $(\mathbf{1} \mathbf{g}$ and $\mathbf{1 j})$ display lower conversion under standard conditions. Increasing the catalyst loading results in improved yields of $\mathbf{3 a g}$ and $\mathbf{3 a j}$ (88\% and $96 \%$, respectively), while maintaining high stereoselectivity ( $\geq 96: 4 \mathrm{er}$ and $>20: 1 d r)$. The presence of an ortho-substituent on alkyne 2 I imparts lower reactivity (46\%), presumably due to steric hindrance. Pyridyl alkyne $\mathbf{2 m}$ converts to allylic $\alpha$-nitroester 3am with a higher catalyst loading. It appears that an aromatic or heteroaromatic substituent on the alkyne is critical for reactivity (see 3an). The absolute configuration of 3ao was confirmed by Xray crystallographic analysis. ${ }^{[20,21]}$

Table 4. Alkyne scope. ${ }^{[a]}$

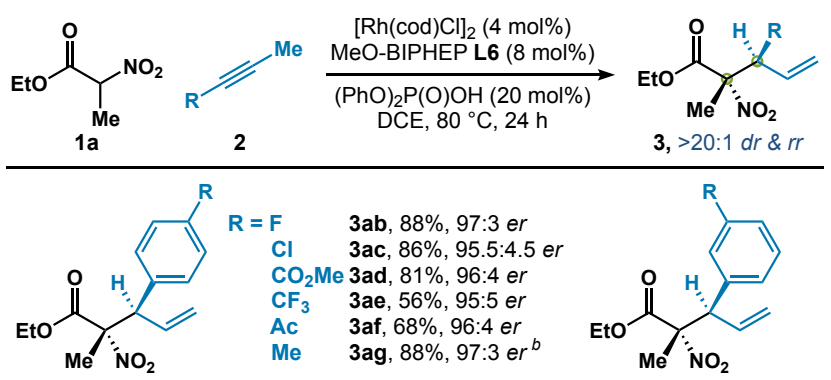

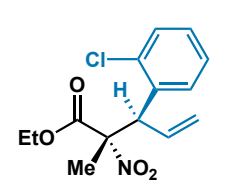

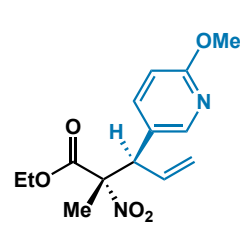

3al, 43\%, 96:4 er

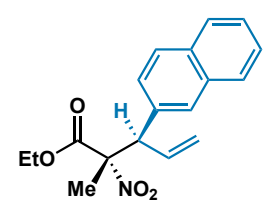

3ao, $46 \%, 97: 3$ er

$$
\mathrm{R}=\mathrm{F} \quad \text { 3ah, 86\%, 98:2 er }
$$
Cl 3ai, 79\%, 96:4 er OMe 3aj, 96\%, 96:4 er Me 3ak, 58\%, 98:2 er

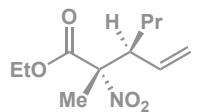

3am, 45\%, 88:12 er 3an, not observed
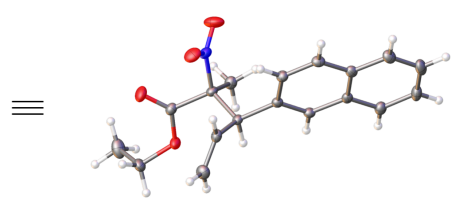

3ao, [X-ray] [a] Isolated yields. See SI for reaction conditions. [b] $[\mathrm{Rh}(\mathrm{cod}) \mathrm{Cl}]_{2}(7.5 \mathrm{~mol} \%)$ and L6 (15 mol\%) instead of standard conditions. [c] 15:1 dr.

A number of further experiments provide evidence in support of the mechanism depicted in Figure 2. First, we monitored a mixture of $[\mathrm{Rh}(\operatorname{cod}) \mathrm{Cl}]_{2}$, MeO-BIPHEP L6, and diphenyl phosphate by ${ }^{1} \mathrm{H}$ NMR spectroscopy. ${ }^{[20]}$ We observe a resonance in the spectrum at $-16.2 \mathrm{ppm}$ (after heating the mixture for $30 \mathrm{~min}$ at $80^{\circ} \mathrm{C}$ ). The observed resonance is consistent with reported values for $\mathrm{Rh}(\mathrm{III})$ $\mathrm{H}$ complexes. ${ }^{[22]}$ This resonance disappears in the ${ }^{1} \mathrm{H}$ NMR spectrum upon the addition of alkyne $\mathbf{2 a}$. Second, we subjected deuterated alkyne $\mathbf{d}-\mathbf{2} \mathbf{a}$ to the standard reaction conditions (Figure 3A). We observe deuterium scrambling into the $\beta-, \gamma-$, and $\delta$-positions of allylic $\alpha$-nitroester $\boldsymbol{d}$-3aa. The incorporation of hydrogen atoms at the $\delta$-position of $\boldsymbol{d}$-3aa supports a reversible $\beta-\mathrm{H}$ elimination in the isomerization pathway. Third, to examine the plausibility of an allene intermediate in the catalytic cycle, we subjected 1-phenylallene (4a) to the standard conditions (Figure $3 B$ ). We observe 3 aa ( $14 \%$ yield) when using an excess of allene 4a. Moreover, the remaining amount of allene $\mathbf{4 a}$ is consumed. These results, which are in agreement with previous reports, suggest that maintaining a low concentration of the allene intermediate $\mathbf{4}$ slows competitive polymerization. ${ }^{10 i, 12 a, 23,24]}$

A. Isotope Labeling Study

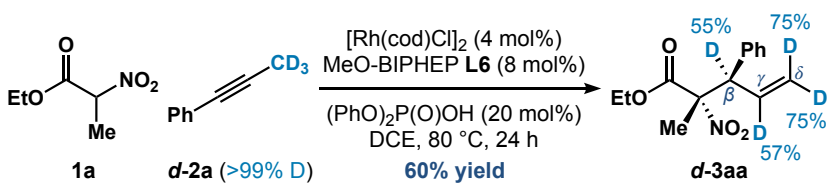

B. Allene Intermediate Study

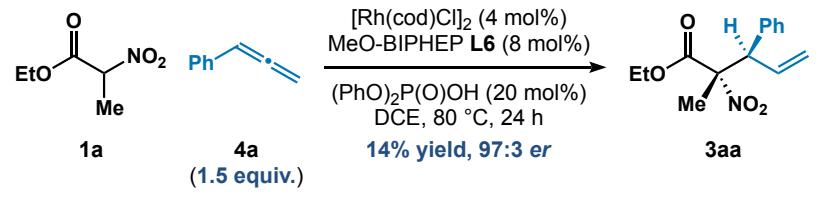

Figure 3. Mechanistic studies.

Treating allylic $\alpha$-nitroester 3aa with In powder readily yields the corresponding $\alpha$-amino ester 6 in $93 \%$ yield (eq 1 ). This simple reduction allows for rapid access to $\alpha$, $\alpha$-disubstituted $\alpha$-amino esters that contain two contiguous stereocenters, without the ablation of preset stereochemistry.<smiles>C=CC(c1ccccc1)[C@H](C)[N+](=O)[O-]</smiles>

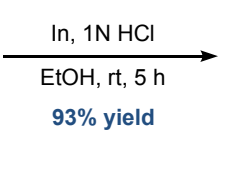

$97: 3 \mathrm{er},>20: 1 d r$

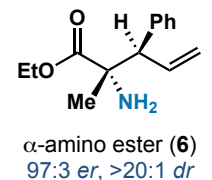

The use of Rh-H catalysis offers a complementary approach to novel $\alpha$-AAs. The allylic $\alpha$-AA surrogates prepared contain an olefin handle that can be used for protein modifications, ${ }^{[25]}$ glycopeptide synthesis, ${ }^{[26]}$ and cyclizations. ${ }^{[27]}$ Our strategy offers a solution to the challenging preparation of contiguous stereocenters in an acyclic framework, with diastereo- and enantiocontrol. Insights from this study will guide related strategies to construct $\mathrm{C}-\mathrm{C}$ bonds with transition-metal catalysis.

\section{Acknowledgements}

Funding provided by UC Irvine and the National Institutes of Health (R35GM127071). We thank Dr. Milan Gembicky (UC San Diego) for X-ray crystallographic analysis. We thank Solvias AG for a generous donation of commercially available MeO-BIPHEP L6 (Catalog \#: SL-A104-1).

\section{References}

[1] (a) de Graaf, A. J.; Kooijman, M.; Hennink, W. E.; Mastrobattista, E. Bioconjugate Chem. 2009, 20, 1281-1295. (b) Hodgson, D. R. W.; Sanderson, J. M. Chem. Soc. Rev. 2004, 33, 422-430. (c) Hohsaka, T.; Sisido, M. Curr. Opin. Chem. Biol. 2002, 6, 809-815. (d) Hendrickson, T. L.; de Crécy-Lagard, V.; Schimmel, P. Annu. Rev. Biochem. 2004, 73, 147-176. (e) Young, D. D.; Schultz, P. G. ACS Chem. Biol. 2018, 13, 854-870.

[2] Liu, C. C.; Schultz, P. G. Annu. Rev. Biochem. 2010, 79, 413-444.

[3] (a) Stevenazzi, A.; Marchini, M.; Sandrone, G.; Vergani, B.; Lattanzio, M. Bioorg. Med. Chem. Lett. 2014, 24, 5349-5356. (b) Blaskovich, M. A. T. J. Med. Chem. 2016, 59, 10807-10836.

[4] (a) Tanaka, M. Chem. Pharm. Bull. 2007, 55, 349-358. (b) Aceña, J. L.; Sorochinsky, A. E.; Soloshonok, V. A. Synthesis 2012, 44, 1591-1602. (c) Porter, M. R.; Xiao, H.; Wang, J.; Smith, S. B.; Topczewski, J. J. ACS Med. Chem. Lett. 2019, 10, 1436-1442. 
[5] For select reviews, see: (a) Cativiela, C.; Díaz-de-Villegas, M. D. Tetrahedron Asymmetry 1998, 9, 3517-3599. (b) Cativiela, C.; Díaz-deVillegas, M. D. Tetrahedron Asymmetry 2007, 18, 569-623. (c) Vogt, H.; Bräse, S. Org. Biomol. Chem. 2007, 5, 406-430. (d) Nájera, C.; Sansano, J. M. Chem. Rev. 2007, 107, 4584-4671. (e) Metz, A. E.; Kozlowski, M. C. J. Org. Chem. 2015, 80, 1-7.

[6] For select examples, see: (a) Trost, B. M.; Ariza, X. Angew. Chem. Int Ed. 1997, 36, 2635-2637. (b) Trost, B. M.; Dogra, K. J. Am. Chem. Soc 2002, 124, 7256-7257. (c) Chen, W.; Hartwig, J. F. J. Am. Chem. Soc. 2013, 135, 2068-2071. (d) Wei, X.; Liu, D.; An, Q.; Zhang, W. Org. Lett. 2015, 17, 5768-5771. (e) Su, Y.-L.; Li, Y.-H.; Chen, Y.-G.; Han, Z.-Y. Chem. Commun. 2017, 53, 1985-1988. (f) Huo, X.; Zhang, J.; Fu, J.; He, R.; Zhang, W. J. Am. Chem. Soc. 2018, 140, 2080-2084. (g) Wei, L.; Zhu, Q.; Xu, S.-M.; Chang, X.; Wang, C.-J. J. Am. Chem. Soc. 2018, 140, 1508-1513. (h) Wu, H.-M.; Zhang, Z.; Xiao, F.; Wei, L.; Dong, X.-Q.; Wang, C.-J. Org. Lett. 2020, 22, 4852-4857.

[7] (a) Zhang, Q.; Yu, H.; Shen, L.; Tang, T.; Dong, D.; Chai, W.; Zi, W. J. Am. Chem. Soc. 2019, 141, 14554-14559. For related studies, see: (b) Goldfogel, M. J.; Meek, S. J. Chem. Sci. 2016, 7, 4079-4084. (c) Zhang Z.; Xiao, F.; Wu, H.-M.; Dong, X.-Q.; Wang, C.-J. Org. Lett. 2020, 22 569-574.

[8] Trost, B. M. Science 1991, 254, 1471-1477.

[9] Kitadai, N.; Maruyama, S. Geosci. Front. 2018, 9, 1117-1153.

[10] For select reviews, see: (a) Haydl, A. M.; Breit, B.; Liang, T.; Krische, M. J. Angew. Chem. Int. Ed. 2017, 56, 11312-11325. (b) Koschker, P.; Breit, B. Acc. Chem. Res. 2016, 49, 1524-1536. (c) Thoke, M. B.; Kang, Q. Synthesis 2019, 51, 2585-2631. (d) Li, G.; Huo, X.; Jiang, X.; Zhang, W. Chem. Soc. Rev. 2020, 49, 2060-2118. For select examples using Pd-H catalysis, see: (e) Kadota, I.; Shibuya, A.; Gyoung, Y. S.; Yamamoto, Y. J. Am. Chem. Soc. 1998, 120, 10262-10263. (f) Patil, N. T.; Kadota, I.; Shibuya, A.; Gyoung, Y. S.; Yamamoto, Y. Adv. Synth. Catal. 2004, 346, 800-804. (g) Yang, C.; Zhang, K.; Wu, Z.; Yao, H.; Lin, A. Org. Lett. 2016, 18, 5332-5335. For select examples of metal-catalyzed alkyne isomerization and trapping with electrophiles, see: (h) Obora, Y.; Hatanaka, S.; Ishii, Y. Org. Lett. 2009, 11, 3510-3513. (i) Park, B. Y.; Nguyen, K. D.; Chaulagain, M. R.; Komanduri, V.; Krische, M. J. J. Am. Chem. Soc. 2014, 136, 11902-11905. (j) Liang, T.; Zhang, W.; Krische, M. J. J. Am. Chem. Soc. 2015, 137, 16024-16027. (k) Liang, T.; Nguyen, K. D.; Zhang, W.; Krische, M. J. J. Am. Chem. Soc. 2015, 137, 31613164. (I) Liang, T.; Zhang, W.; Chen, T.-Y.; Nguyen, K. D.; Krische, M. J. J. Am. Chem. Soc. 2015, 137, 13066-13071. (m) Zhang, W.; Chen, W.; Xiao, H.; Krische, M. J. Org. Lett. 2017, 19, 4876-4879.

[11] Wolf, J.; Werner, H. Organometallics 1987, 6, 1164-1169.

[12] For examples of asymmetric $\mathrm{C}-\mathrm{N}$ bond formation, see: (a) Chen, Q.-A.; Chen, Z.; Dong, V. M. J. Am. Chem. Soc. 2015, 137, 8392-8395. (b) Haydl, A. M.; Hilpert, L. J.; Breit, B. Chem. Eur. J. 2016, 22, 6547-6551. (c) Berthold, D.; Breit, B. Org. Lett. 2018, 20, 598-601. For examples of asymmetric C-O bond formation, see: (d) Liu, Z.; Breit, B. Angew. Chem Int. Ed. 2016, 55, 8440-8443. (e) Koschker, P.; Kähny, M.; Breit, B. J. Am. Chem. Soc. 2015, 137, 3131-3137. For related racemic couplings of heteroatom nucleophiles and alkynes, see: (f) Lumbroso, A.; Koschker, P.; Vautravers, N. R.; Breit, B. J. Am. Chem. Soc. 2011, 133 2386-2389. (g) Xu, K.; Khakyzadeh, V.; Bury, T.; Breit, B. J. Am. Chem. Soc. 2014, 136, 16124-16127.

[13] (a) Cruz, F. A.; Dong, V. M. J. Am. Chem. Soc. 2017, 139, 1029-1032. (b) Cruz, F. A.; Zhu, Y.; Tercenio, Q. D.; Shen, Z.; Dong, V. M. J. Am Chem. Soc. 2017, 139, 10641-10644. (c) Xie, L.; Yang, H.; Ma, M.; Xing, D. Org. Lett. 2020, 22, 2007-2011. For a related study that uses Rh-H catalysis and affords enantioenriched linear products, see: (d) Ji, D.-W.; Yang, F.; Chen, B.-Z.; Min, X.-T.; Kuai, C.-S.; Hu, Y.-C.; Chen, Q.-A. Chem. Commun. 2020, 56, 8468-8471.

[14] For selected examples, see: (a) Cruz, F. A.; Chen, Z.; Kurtoic, S. I.; Dong V. M. Chem. Commun. 2016, 52, 5836-5839. (b) Li, C.; Grugel, C. P.; Breit, B. Chem. Commun. 2016, 52, 5840-5843. (c) Beck, T. M.; Breit, B. Eur. J. Org. Chem. 2016, 35, 5839-5844. (d) Beck, T. M.; Breit, B Org. Lett. 2016, 18, 124-127. (e) Zheng, W.-F.; Xu, Q.-J.; Kang, Q. Organometallics 2017, 36, 2323-2330.

[15] For examples of $\alpha$-nitroesters coordinating to Lewis acids, see: (a) Keller, E.; Veldman, N.; Spek, A. L.; Feringa, B. L. Tetrahedron Asymmetry
1997, 8, 3403-3413. (b) Keller, E.; Feringa, B. L. Synlett 1997, 7, 842844.

[16] Kornblum, N.; Blackwood, R. K.; Powers, J. W. J. Am. Chem. Soc. 1957, 10, 2507-2509.

[17] (a) Ohmatsu, K.; Ito, M.; Kunieda, T.; Ooi, T. Nat. Chem. 2012, 4, 473477. For related studies that use symmetric allyl partners with $\mathrm{Pd}$ catalysis, see: (b) Sawamura, M.; Nakayama, Y.; Tang, W.-M.; Ito, Y. J. Org. Chem. 1996, 61, 9090-9096. (c) Maki, K.; Kanai, M.; Shibasaki, M. Tetrahedron 2007, 63, 4250-4257. (d) Trost, B. M.; Surivet, J.-P. Angew. Chem. Int. Ed. 2000, 39, 3122-3124. (e) Trost, B. M.; Surivet, J.-P. J. Am. Chem. Soc. 2000, 122, 6291-6262.

[18] (a) Shipchandler, M. T. Synthesis 1979, 9, 666-686. (b) N. Ono, The Nitro Group in Organic Synthesis, Wiley, New York, 2001.

[19] For an example of enantioselectivity changing as a function of ligand dihedral angle, see: Shimizu, H.; Nagasaki, I.; Matsumura, K.; Sayo, N.; Saito, T. Acc. Chem. Res. 2007, 40, 1385-1393.

[20] See the Supporting Information for more details.

[21] CCDC 2014416 (3fa) and CCDC 2014415 (3ao) contain the supplementary crystallographic data for this report. These data can be obtained free of charge from The Cambridge Crystallographic Data Centre. The absolute configurations of the remaining allylic $\alpha-A A$ surrogates 3 were assigned by analogy.

[22] For select examples, see: (a) Giuseppe, A. D.; Castarlenas, R.; PérezTorrente, J. J.; Crucianelli, M.; Polo, V.; Sancho, R.; Lahoz, F. J.; Oro, L. A. J. Am. Chem. Soc. 2012, 134, 8171-8183. (b) Giuseppe, A. D.; Castarlenas, R.; Pérez-Torrente, J. J.; Lahoz, F. J.; Oro, L. A. Chem. Eur. J. 2014, 20, 8391-8403. (c) Yang. X.-H.; Davison, R. T.; Nie, S.-Z.; Cruz, F. A.; McGinnis, T. M.; Dong, V. M. J. Am. Chem. Soc. 2019, 141, 30063013.

[23] For examples of transition metal-catalyzed 1-phenylallene polymerization, see: (a) Osakada, K.; Choi, J.-C.; Koizumi, T.-A.; Yamaguchi, I.; Yamamoto, T. Organometallics 1995, 14, 4962-4965. (b) Takagi, K.; Tomita, I.; Endo, T. Macromolecules 1997, 30, 7386-7390.

[24] In agreement with this statement, when we lower the amount of allene used to 0.3 equivalents, we observe 3 aa in $48 \%$ yield (based on allene as the limiting reagent).

[25] (a) Lin, Y. A.; Chalker, J. M.; Davis, B. G. ChemBioChem 2009, 10, 959969. (b) deGruyter, J. N.; Malins, L. R.; Baran, P. S. Biochemistry 2017, 56, 3863-3873.

[26] Gamblin, D. P.; Scanlan, E. M.; Davis, B. G. Chem. Rev. 2009, 109, 131163.

[27] White, C. J.; Yudin, A. K. Nat. Chem. 2011, 3, 509-524. 


\section{Table of Contents Graphic}

$\overbrace{\mathbf{R}}^{\mathrm{NO}_{\mathbf{R}}} \underset{\mathrm{NO}_{2}}{\frac{\mathrm{Rh}-\mathrm{H} \text { catalyst }}{\text { up to } 98: 2 \mathrm{er},>20: 1 d r}}$

( \pm

readily available material

amino acid surrogates 